\title{
Pengembangan Perangkat Pembelajaran Berbasis ICT Memanfaatkan Power Point, Filmora, Whtasapp Grup, Google Classroom, dan Google Formulir Untuk Meningkatkan Keefektifan Pembelajaran
}

\author{
Hafizd Darmawan ${ }^{1}$, Mangaratua M. Simanjorang ${ }^{2}$, Hamidah Nasution ${ }^{3}$ \\ ${ }^{1,2,3}$ Prodi Pendidikan Matematika Pascasarjana, Universitas Negeri Medan \\ Universitas Negeri Medan, Jalan William IskandarPasar V, Medan, Indonesia \\ hafizdnasution@gmail.com
}

\begin{abstract}
This research is motivated by the impact of COVID-19 on the learning process which causes distance orlearning online. So that an alternative or solution is needed in designing mathematics learning to increase the effectiveness of learning. The media used in learning are Power Point, Filmora, Whatsapp Group, Google Classroom, and Google Forms. This research is development research that refers to the 4-D model. The 4-D model was developed by Thiagarajan which includes defin, design, development, and disseminate activities. Based on the results of the study, it was obtained that the ICT-based learning design tools utilize power point, filmora, whatsapp group, google classroom, and google forms to increase the effectiveness of student learning outcomes that were developed that met the valid, practical, and effective criteria. The average validity of lesson plans is 4.26 , the average student worksheet validity is 4.21 , the average learning video validity is 4.17 , the average learning outcomes test validity is 4.28 , with categories valid. Practicality in terms of the implementation of learning devices on the IO criteria $=4.5$ high. The effectiveness in terms of increasing student learning outcomes using learning tools that have been developed is seen from the $\mathrm{N}$-gain value in the first trial of 0.4 increasing to 0.6 in the second trial, meaning that it is in the "medium" category.
\end{abstract}

Keywords: Learning Design, ICT, Learning Effectiveness

\begin{abstract}
Abstrak
Peneltian ini dilatarbelakangi dampak COVID-19 pada proses pembelajaran yang menyebabkan pembelajaran jarak jauh atau daring. Sehingga dibutuhkan alternatif atau solusi dalam mendesain pembelajaran matematika untuk meningkatkan keefektifan pembelajaran. Media-media yang digunakan dalam pembelajaran ialah Power Point, Filmora, Whatsapp Grup, Google Classroom, dan Google Formulir. Penelitian ini merupkan penelitian pengembangan yang mengacu pada model 4-D. Model 4-D dikembangkan oleh Thiagarajan yang meliputi kegiatan define (pendefinisian), design (perancangan), development (pengembangan), dan disseminate (penyebarluasan). Berdasarkan hasil penelitian diperoleh perangkat desain pembelajaran berbasis ICT memanfaatkan power point, filmora, whatsapp grup, google classroom, dan googel formulir untuk meningkatkan keefektifan hasil belajar siswa yang dikembangkan sudah memenuhi kriteria valid, praktis dan efektif. Kevalidan dengan rata-rata validitas RPP sebesar 4,26, rata-rata validitas lembar kerja peserta didik sebesar 4,21, rata-rata validitas video pembelajaran sebesar 4,17, rata-rata validitas tes hasil belajar sebesar 4,28, dengan kategori valid. Kepraktisan ditinjau dari Keterlaksanaan perangkat pembelajaran pada kriteria $I O=4,5$ tinggi. Keefektifan ditinjau dari peningkatan hasil belajar siswa menggunakan perangkat pembelajaran yang telah dikembangkan dilihat dari nilai $N$-gain pada uji coba I sebesar 0,4 meningkat menjadi 0,6 pada uji coba II, artinya berada dalam kategori "sedang".
\end{abstract}

Kata kunci: Desain Pembelajaran, ICT, Keefektifan Pembelajaran

Copyright (c) 2022 Hafizd Darmawan, Mangaratua M. Simanjorang, Hamidah Nasution $\triangle$ Corresponding author: Hafizd Darmawan

Email Address: hafizdnasution@gmail.com (Jalan William Iskandar Pasar V, Medan, Indonesia)

Received 13 January 2022, Accepted 27 January 2022, Published 11 February 2022

\section{PENDAHULUAN}

Perkembangan ilmu pengetahuan dan teknologi merupakan suatu kebutuhan sekaligus tuntuan di era globalisasi khususnya dalam bidang pendidikan. Penggunaan teknologi dalam bidang pendidikan menuntut para pendidik lebih kreatif dan inovatif untuk memenfaatkan teknologi sebgai upaya meningkatkan kualitas pendidikan guna tercapainya tujuan pembelajaran. Menurut Oktaviyanthi (Azriati, 2020) ICT (Information and Communication Technology) telah banyak 
Pengembangan Perangkat Pembelajaran Berbasis ICT Memanfaatkan Power Point, Filmora, Whtasapp Grup, Google Classroom, dan Google Formulir Untuk Meningkatkan Keefektifan Pembelajaran, Hafizd Darmawan, Mangaratua M. Simanjorang, Hamidah Nasution

memberikan banyak perubahan pada kehidupan manusia, baik dalam bekerja, berinteraksi dan memperoleh pengetahuan. Perkembangan ICT pada sector pendidikan memberi peluang baru, pengaruh baik dan kontribusi positif.

Dunia pendidikan saat ini semakin berkembang, banyak pembaharuan yang dilakukan demi meningkatkan kualitas pendidikan. Sebagaimana defenisi pendidikan menurut Undang Undang (2003) yaitu pendidikan adalah usaha sadar dan terencana untuk mewujudkan suasana belajar dan proses pembelajaran agar peserta didik secara aktif mengembangkan potensi dirinya untuk memiliki kekuatan spiritual keagamaan, pengendalian diri, kepribadian, kecerdasan, akhlak mulia, serta keterampilan yang diperlukan dirinya, masyarakat, bangsa dan Negara. Dengan demikian, pendidikan adalah proses dari rencana yang terstruktur untuk mewujudkan pembelajaran yang berhasil dalam hal kepribadian, akhlak, moral dan membentuk insane yang berguna bagi bangsa dan Negara. Hal ini senada dengan Trianto (Trianto, 2011) yang mengemukakan bahwa, pendidikan bertujuan untuk mengembangkan potensi peserta didik agar menjadi manusia yang beriman dan bertaqwa kepada Tuhan Yang Maha Esa, berakhlak mulia, sehat, berilmu, cakap, kreatif, mandiri, dan menjadi warga negara yang demokratis serta bertanggung jawab. Untuk meningkatkan kualitas pendidikan, dibutuhkan berbagai cara dalam inovasi, kurikulum dan sarana prasarana pendidikan untuk meningkatkan proses pembelajaran.

Proses pembelajaran pada satuan pendidikan diselenggarakan secara interaktif, inspiratif, menyenangkan, menantang, memotivasi siswa untuk aktif dan dapat memberikan ruang kepada siswa untuk mengembangkan kreativitas, dan kemandirian sesuai dengan bakat, minat dan perkembangan fisik serta psikologis peserta didik. Proses belajar mengajar merupakan suatu kegiatan melaksanakan kurikulum dengan tujuan tercapainya tujuan pendidikan. Tujuan pendidikan adalah menghantarkan peserta didik menuju perubahan perubahan perilaku baik intelektual, moral, maupun social agar dapat hidup mandiri sebagai individu dan makhluk social. Dalam mencapai tujuan tersebut, peserta didik berinteraksi dengan lingkungan belajar yang diatur guru melalui proses pembelajaran (Sudjana \& Rivai, 1990). Untuk itu, setiap satuan pendidikan perlu melakukan perencanaan pembelajaran, pelaksanaan serta penilaian yang matang dan sesuai zaman untuk meningkatkan efisiensi dan efektivitas demi tercapainya kualitas terbaik dari lulusan lulusan yang berkompetensi unggul.

Menurut Riyana (Azriati, 2020) melalui media suatu proses pembelajaran bisa lebih menarik dan menyenangkan. Hal ini dipertegas dari pendapat Asyhar (Azriati, 2020) yang mengatakan media pembelajaran sebagai sumber belajar merupakan suatu komponen sistem pembelajaran yang meliputi pesan dan informasi, yang dapat mempengaruhi hasil belajar peserta didik.

Salah satu cara memanfaatkan ICT dalam membuat sebuah media yang dapat digunakan dalam proses pembelajaran adalah dengan multimedia presentasi. Multimedia presentasi digunakan untuk menjelaskan materi baik kepada kelompok kecil maupun kelompok besar. Dalam pemanfaatannya, media ini menggunakan projector/LCD yang jangkaunnya cukup luas sehingga cukup efektif (Munadi, 2008). Salah satu perangkat lunak yang sering digunakan dalam presentasi adalah 
PowerPoint. Aplikasi ini sering digunakan karena memiliki beberapa kelebihan seperti, mampu menampilkan objek yang sebenarnya secara nyata taka da atau imagery (Herlanti dalam (Munadi, 2008)) dan juga mampu menggabungkan unsur-unsur media seperti teks, video, animasi, gambar, grafik, dan suara.

Mulai tahun 2020 Indonesia dan berbagai negara di belahan dunia lainnya tangah dihadapkan dengan pandemic yang disebabkan oleh virus coronavirus. Coronavirus merupakan virus jenis baru (SARS-CoV-2) dan penyakitnya disebut Coronavirus disesase 2019 (COVID-19) yang berasal dari Wuhan, Tiongkok pada akhir Desember 2019 (Yuliana, 2020). Virus ini dapat ditularkan dari manusia ke manusia dan telah menyebar secara luas di lebih dari 190 negara sehingga pada 12 Maret 2020, WHO mengumumkan COVID-19 sebagai pandemic (Susilo et al., 2020). Pandemi COVID-19 ini memberikan dampak yang besar bagi kehidupan manusia. Dilansir dari detiknews sampai hari ini kasus COVID-19 di Indonesia menyentuh angka 271 ribu dengan jumlah pasien meninggal sebanyak 10 ribu orang. Dampak COVID-19 ini menyerang berbagai aspek salah satunya pendidikan. Untuk memutus mta rantai penyebaran COVID-19 di Indonesia, Pemerintah melalui Kemendikbud menerbitkan Surat Edaran Nomor 3 Tahun 2020 tentang Pencegahan COVID-19 pada satuan Pendidikan. Program belajar dari rumah ini telah diterapkan dari berbagai tingkaran pendidikan di Indonesia (Kemendikbud, 2020).

Upaya proses pembelajaran tetap terselenggara, sekolah-sekolah pun memanfaatkan perkembangan teknologi, informasi dan komunikasi yaitu dengan menerapkan pembelajaran daring terlaksana dengan lebih mudah. Daring merupakan pemanfaatan jaringan internet dalam proses pembelajaran (Isman dalam (Suswandari et al., 2020)). Pembelajaran daring menjadi alternatik untuk menyelenggarakan proses pembelajaran.

Mata pelajaran Matematika merupakan pelajaran yang diberikan sejak sekolah dasar hingga perguruan tinggi. Hal ini karena pada pelajaran matematika siswa diajarkan bertindak kreatif, logis, sistematis, analitis, dan kritis. Ini telah tertuang dalam Peraturan Menteri Pendidikan Nasional Republik Indonesia (Permendiknas) pada tahun 2006 nomor 22 yaitu "Mata pelajaran matematika perlu diberikan kepada semua peserta didik mulai sekolah dasar untuk membekali siswa dengan kemampuan berpikir logis, analitis, sistematis, kritis, dan kreatif serta memiliki kemampuan bekerja sama". Berdasarkan pemaparan diatas, Matematika adalah ilmu universal yang mendasari perkembangan teknologi modern. Matematika memiliki peran penting dalam memajukan daya pikir manusia. Matematika sangat perlu diberikan kepada peserta didik untuk membekali mereka kemampuan berpikir logis, analitis, sistematis. Dalam membelajarkan matematika kepada siswa membutuhkan komunikasi yang tidak monoton sehingga tidak mengakibatkan siswa merasa jenuh dan bosan (Daryanto, 2012).

Diabad 21 sekarang ini, Indonesia telah memasuki era industry 4.0 yang bercirikan pemanfaatan teknologi digital dalam proses pembelajaran dan mampu membuat proses pembelajaran berlangsung secara kontinu tanpa batas ruang dan tanpa batas waktu. Sehingga pembelajaran yang 
Pengembangan Perangkat Pembelajaran Berbasis ICT Memanfaatkan Power Point, Filmora, Whtasapp Grup, Google Classroom, dan Google Formulir Untuk Meningkatkan Keefektifan Pembelajaran, Hafizd Darmawan, Mangaratua M. Simanjorang, Hamidah Nasution

memadukan antara Teknologi informasi dan pembelajaran matematika dipandang tepat pada saat sekarang ini dan masa depan karena pembelajaran dapat dilakukan dimanapun dan kapanpun tanpa ada batas ruang dan waktu. Berdasarkan pemaparan diatas, maka penulis tertarik untuk melakukan penelitian dengan judul "Pengembangan Media Pembelajaran Berbasis ICT Memanfaatkan PowerPoint, Filmora, WhatsApp Grup, Google Classroom, dan Google Document Untuk Memaksimalkam Keefektifan Pembelajaran”.

\section{METODE}

Penelitian ini termasuk dalam penelitian pengembangan (Development Research). Penelitian ini menggunakan model pengembangan 4D. Penelitian ini berpusat untuk mengembangkan media pembelajaran matematika berbasis ICT (Information and Communication Technologies). Penelitian ini dilaksanakan di SMPS An-Nizam, Jl. Tuba II No.62, Tegal Sari Mandala III, Kec. Medan Denai, Kota Medan, Sumatera Utara 20226 pada siswa kelas VII Semester I Tahun Pelajaran 2021/2022. Populasi dalam Penelitian ini adalah kelas VII KH Ahmad Dahlan SMPS An-Nizam Kota Medan Tahun Pelajaran 2021/2022, sedangkan sampel dalam penelitian ini adalah siswa kelas VII. Objek dalam Penelitian ini adalah media pembelajaran matematika berbasis ICT (Information and Communication Technologies). Model penelitian pengembangan yang digunakan menurut (Trianto, 2011) adalah model pengembangan 4D (Four D) dengan tahapan yaitu: pendefenisian (define), perancangan (design), pengembangan (develop), dan penyebaran (disseminate).

\section{Analisis Data Validasi Media Pembelajaran}

Penentuan kevalidan media pembelajaran berbasis ICT (Information and Communication Technologies) mengikuti langkah langkah berikut:

1. Melakukan rekapitulasi data penilaian kevalidan media pembelajaran kedalam tabel yang meliputi: aspek $\left(\left(A_{1}\right)\right.$, Indikator $\left(I_{i}\right)$, dan Nilai $\left(V_{j i}\right)$, untuk tiap tiap ahli

2. Menentukan rata rata nilai dari ahli untuk setiap indicator dengan rumus : $\left(I_{i}\right)=\frac{\sum_{j=1}^{n} V_{j i}}{n}$

(Sinaga, 2007)

$V_{j i}=$ data nilai dari penilai $\mathrm{ke}-\mathrm{j}$ terhadap indicator $\mathrm{ke}-\mathrm{i}$

$n=$ banyak nya penilai (ahli)

Hasil yang diperoleh kemudian ditulis pada kolom dalam tabel.

3. Menentukan rata rata nilai untuk setiap aspek dengan rumus:

$$
\left(A_{i}\right)=\frac{\sum_{j=1}^{m} I_{i j}}{m}
$$

$A_{i}=$ rata rata nilai untuk aspek $\mathrm{ke}-\mathrm{i}$

$I_{i j}=$ rata rata untuk aspek ke $-\mathrm{i}$ indicator $\mathrm{ke}-\mathrm{j}$

$m=$ banyak indicator dalam aspek $\mathrm{ke}-\mathrm{i}$ 
Hasil yang diperoleh kemudia ditulis pada kolom dalam tabel

4. Menentukan nilai Va atau nilai rata rata total dari rata rata nilai semua aspek dengan rumus

$$
\left(V_{a}\right)=\frac{\sum_{i=1}^{n} A_{i}}{n}
$$

$\mathrm{Va}=$ nilai rata-rata total untuk semua aspek

$A_{i}=$ rata rata nilai untuk aspek ke $-\mathrm{I}$

$n=$ banyak aspek

Tabel 1. Kriteria Tingkat Kevalidan Media Pembelajaran

\begin{tabular}{|c|c|c|}
\hline No & Va atau Nilai rata rata total & Criteria Kevalidan \\
\hline 1 & $3,5<V a \leq 4$ & Sangat Valid \\
\hline 2 & $2,5<V a \leq 3,5$ & Valid \\
\hline 3 & $1,5<V a \leq 2,5$ & Kurang Valid \\
\hline 4 & $1 \leq V a \leq 1,5$ & Tidak Valid \\
\hline
\end{tabular}

\section{Analisis Data Peningkatan Hasil Belajar siswa}

Untuk mengetahui peningkatan hasil belajar siswa, data diperoleh dari hasil pretest dan posttest hasil belajar. Peningkatan hasil belajar ini dapat diperoleh dari data indeks gain ternormalisasi sebagai berikut (Hake, 1999):

$$
N-\text { Gain }=\frac{\text { post test }- \text { pre test }}{\text { skor ideal-pretest }}
$$

Criteria indeks Gain Ternormalisasi (g) adalah:

$g>0,7:$ tinggi

$0,3<g \leq 0,7$ : sedang

$g \leq 0,3:$ rendah

\section{Analisis Data Efektifitas Media Pembelajaran}

Data diperoleh dari tes hasil belajar. Setelah diberikan pembelajaran menggunakan media pembelajaran berbasis ICT (Information and Communication Technologies) yang telah dikembangkan. Hasil tes dari uji coba 1 dan uji coba 2 dibandingkan untuk dilihat keefektifannya. Keefektifan pembelajaran dilihat dari indikator indikator pencapaian tujuan yang diharapkan, yang ditunjukkan dengan (a) Tingkat hasil belajar siswa secara klasikal minil 85\% dari jumlah siswa keseluruhan yang mengikuti pembelajaran menggunakan media berbasis ICT (Information and Communication Technologies) memiliki hasil tes yang baik yaitu minimal melewati nilai KKM yang di tetapkan disekolah tersebut. (b) Pencapaian presentase waktu pembelajaran minimal sama dengan pembelajaran biasa.

\section{Analisis Data Hasil Belajar siswa}

Setiap siswa dikatakan memiliki hasil belajar yang baik jika proporsi skor yang diperoleh minimal 2,85 (B) sesuai konversi 4 berdasarkan nilai ketuntasan kompetensi pengetahuan Permendikbud No. 104 tahun 2014. 
Pengembangan Perangkat Pembelajaran Berbasis ICT Memanfaatkan Power Point, Filmora, Whtasapp Grup, Google Classroom, dan Google Formulir Untuk Meningkatkan Keefektifan Pembelajaran, Hafizd Darmawan, Mangaratua M.

Tabel 2. Kriteria Ketuntasan Hasil Belajar siswa

\begin{tabular}{|c|c|c|}
\hline \multicolumn{3}{|c|}{ Nilai Ketuntasan } \\
\hline Rentang Angka & Rentang Nilai & Huruf \\
\hline $3,85-4,00$ & $96,25-100$ & A \\
\hline $3,51-3,84$ & $87,75-96,24$ & $A^{-}$ \\
\hline $3,18-3,50$ & $79,50-87,50$ & $B^{+}$ \\
\hline $2,85-3,17$ & $71,25-79,49$ & B \\
\hline $2,51-2,84$ & $62,75-71,24$ & $B^{-}$ \\
\hline $2,18-2,50$ & $54,50-62,74$ & $C^{+}$ \\
\hline $1,85-2,17$ & $46,25-54,49$ & C \\
\hline $1,51-1,84$ & $37,75-46,24$ & $C^{-}$ \\
\hline $1,18-1,50$ & $29,50-37,74$ & $D^{+}$ \\
\hline $1,00-1,17$ & $<29,50$ & $D$ \\
\hline
\end{tabular}

\section{Analisis Data Pencapaian Waktu}

Data ini diperoleh dengan melihat pencapaian waktu yang digunakan dalam proses pembelajaran. Jika pencapaian waktu yang digunakan selama pembelajaran lebih kurang sama dengan waktu pembelajran biasa, maka pencapaian waktu dikatakan baik.

\section{Analisis Data Kepraktisan Media Pembelajaran}

Untuk menguji kepraktisan media pembelajaran, maka media yang dikembangkan berbasiss ICT (Information and Communication Technologies) dalam penelitian ini dihitung nilai angket kepraktisan dari guru dan siswa dengan teknik analisis data sebagai mana menghitung validitas pengembangan media belajar yaitu:

Tabel 3. Kriteria Tingkat Keprsktisan Media Pembelajaran

\begin{tabular}{|c|c|c|}
\hline No & Va Atau Nilai rata rata Total & Kriteria Kepraktisan \\
\hline 1 & $3,5<\mathrm{Va} \leq 4$ & Sangat Praktis \\
\hline 2 & $2,5<\mathrm{Va} \leq 3,5$ & Praktis \\
\hline 3 & $1,5<\mathrm{Va} \leq 2,5$ & Kurang Praktis \\
\hline 4 & $1<\mathrm{Va} \leq 1,5$ & Tidak Praktis \\
\hline
\end{tabular}

\section{HASIL DAN DISKUSI}

Penelitian ini merupakan penelitian pengembangan (development research). Produk yang dikembangkan pada penelitian ini adalah desain pembelajaran memanfaatkan media berbasis ICT sehingga memenuhi kriteria validitas, kepraktisan dan keefektivan. Perangkat pembelajaran yang dikembangkan meliputi rencana pelaksanaan pembelajaran (RPP), lembar kerja peserta didik (LKPD), video pembelajaran, dan tes hasil belajar siswa. Perangkat pembelajaran dikembangkan dengan menggunakan model pengembangan 4-D dari Thiagarajan. yang meluputi empat tahapan yaitu 
pendefenisian, perancangan, pengembangan dan penyebaran. Setiap tahap dilakukan secara berkesinambungan.

\section{Tahap Pendefinisian (Define)}

Berdasarkan hasil observasi dan analisis terhadap perangkat pembelajaran di SMP An Nizam Medan, menunjukkan bahwa guru sudah memiliki perangkat pembelajaran, tetapi jarang digunakan di dalam proses pembelajaran. Rencana pelaksanaan pembelajaran (RPP) yang ada bukan merupakan gambaran dari proses pembelajaran yang dilaksanakan, karena pada masa ini kepala sekolah menerapkan pembelajaran Hybrid (setengah pembelajaran luring, setengah pembelajaran daring) sedangkan RPP yang dipersiapkan oleh guru ialah sesuai dengan Kurikulum 2013. LKPD yang ada digunakan tidak singkron dengan RPP, sehingga tujuan pembelajaran yang diinginkan pada RPP tidak terdapat dalam LKPD yang ada dan bagi siswa yang daring seperti kurang mendapat perhatian karena tugas dan penjelasan disajikan dalam papan tulis sehingga penglihatan mereka terbatas. Selain itu, dalam proses pembelajaran siswa tidak dilibatkan dalam proses menemukan pengetahuannya melainkan langsung diberikan oleh guru. Kepala Sekolah memang juga menerapkan video pembelajaran dalam solusi pembelajaran terbatas, tetapi guru hanya beberapa kali menggunakan video pembelajaran dalam proses pembelajaran. Mungkin karena tuntutan dari Kepala Sekolah sehingga para guru membuat satu video pembelajaran sesuai dengan ketentuan tersebut.

Berdasarkan uraian di atas, terlihat bahwa ada masalah dalam proses pembelajaran matematika di SMP An Nizam Medan. Untuk mengatasi masalah tersebut perlu dikembangkan desain pembelajaran memanfaatkan media berbasis ICT. Dengan mengembangkan desain pembelajaran memanfaatkan media berbasis ICT, siswa mendapatkan pembelajaran yang sama rata, baik yang daring dan luring. Dengan demikian pembelajaran menjadi lebih efektif.

\section{Tahap Perancangan (Design)}

Pada tahap rancangan awal dihasilkan rencana pelaksanaan pembelajaran untuk dua kali pertemuan pada uji coba lapangan, dan tes hasil belajar siswa. Semua hasil pada tahap perancangan ini disebut Draft Awal. Secara garis besar hasil perancangan awal adalah sebagai berikut :

\section{Rencana Pelaksanaan Pembelajaran (RPP)}

Rencana Pelaksanaan Pembelajaran (RPP) terdiri dari 2 kali pertemuan. Kedua RPP tersebut dijabarkan sebagai berikut:

1. Rencana Pelaksanaan Pembelajaran I

Alokasi waktu yang digunakan pada RPP I adalah 2 x 30 menit dengan materi segiempat. Indikator pencapaian hasil belajar dijabarkan sebagai berikut:

a. Siswa mampu menetukan luas dan keliling persegi.

b. Siswa mampu menentukan luas dan keliling persegi panjang.

c. Siswa mampu menentukan luas dan keliling belah ketupat.

2. Rencana Pelaksanaan Pembelajaran II

Alokasi waktu yang digunakan pada RPP II adalah 2 x 30 menit dengan materi segiempat. 
Pengembangan Perangkat Pembelajaran Berbasis ICT Memanfaatkan Power Point, Filmora, Whtasapp Grup, Google Classroom, dan Google Formulir Untuk Meningkatkan Keefektifan Pembelajaran, Hafizd Darmawan, Mangaratua M. Simanjorang, Hamidah Nasution

Indikator pencapaian hasil belajar dijabarkan sebagai berikut:

a. Siswa mampu menentukan luas dan keliling jajar genjang.

b. Siswa mampu menentukan luas dan keliling trapesium.

c. Siswa mampu menentukan luas dan keliling layang-layang.

\section{Lembar Kerja Peserta Didik (LKPD)}

Lembar Kerja Peserta Didik (LKPD) dalam penelitian ini sebanyak 2 jenis. LKPD diberikan di setiap pertemuan dengan topik yang sesuai dengan materi segiempat pada pertemuan tersebut. Proses pengerjaan LKPD dilakukan secara individu. Pada LKPD disediakan petunjuk pengerjaan, tempat untuk menuliskan nama, kelas, serta jawaban untuk setiap pertanyaan. LKPD berisi soal yang terpadu dengan masalah pada video pembelajaran, sehingga video pembelajaran dan LKPD dalam penelitian ini merupakan bagian yang tidak terpisahkan. LKPD ini akan dibagikan melalui Whatsapp Grup dengan memanfaatkan Google Classroom.

\section{Tes Hasil Belajar (THB)}

Tes yang dikembangkan sebanyak 4 soal berbentuk uraian yang terdiri dari 4 (empat) soal materi segiempat materi segiempat. Waktu yang disediakan untuk menyelesaikan tes adalah 2 × 30 menit. Tes hasil belajar ini akan dibagikan melalui Whatsapp Grup dengan memanfaatkan Google Formulir.

\section{Tahap Pengembangan (Develop)}

Validator yang melakukan validasi terhadap perangkat pembelajaran yang dikembangkan terdiri dari 5 orang meliputi 3 orang dosen pendidikan matematika UNIMED, 1 orang Guru SMP An Nizam dan 1 orang Guru MTs PAB-1 Helvetia.

Tabel 4. Rekapitulasi Hasil Validasi Perangkat Pembelajaran oleh Ahli

\begin{tabular}{|c|l|c|c|}
\hline No & Objek yang dinilai & $\begin{array}{c}\text { Nilai rata-rata } \\
\text { total validasi }\end{array}$ & $\begin{array}{c}\text { Tingkat } \\
\text { Validasi }\end{array}$ \\
\hline 1. & Video Pembelajaran & 3,75 & Valid \\
\hline 2. & Rencana Pelaksanaan Pembelajaran (RPP) & 3,68 & Valid \\
\hline 3. & Lembar Kerja Peserta Didik (LKPD) & 3,66 & Valid \\
\hline 4. & Tes Awal Hasil Belajar Siswa & 3,85 & Valid \\
\hline 5. & Tes Akhir Hasil Belajar Siswa & 3,89 & Valid \\
\hline
\end{tabular}

Berdasarkan Tabel 4, didapat rata-rata total validitas perangkat pembelajaran berada pada interval: $3 \leq V a<4$. Berdasarkan kriteria kevalidan maka dapat dikatakan bahwa perangkat pembelajaran yang dikembangkan "Valid".

Berdasarkan kriteria keterlaksanaan pembelajaran maka dapat disimpulkan bahwa, keterlaksanaan perangkat pembelajaran pada pertemuan pertama memiliki tingkat keterlaksanaan pembelajaran berada pada kriteria $I O=4,5$, tinggi $(4 \leq I P<5)$. Secara umum, pada Uji Coba ini, memiliki tingkat keterlaksanaan pembelajaran $I O=4,5$, tinggi. Dengan demikian, perangkat pembelajaran telah memenuhi kriteria praktis secara empiris. 
Tes hasil belajar siswa dilakukan satu kali diawal sebelum kegiatan pembelajaran dimulai yang disebut dengan Pre-Test dan satu kali diakhir pembelajaran setelah melaksanakan dua kali pertemuan kegiatan belajar mengajar yang disebut dengan Post-Test. Pemberian Pre-Test dan PostTest bertujuan untuk mengetahui peningkatan hasil belajar siswa yang diperoleh siswa setelah diberi perlakuan pembelajaran pada materi segiempat. Adapun data hasil uji coba dapat dilihat pada Tabel 5. dibawah ini:

Tabel 5. Tingkat Ketuntasan Pre-Test dan Post-Test Hasil Belajar Siswa Pada Uji Coba II

\begin{tabular}{|c|c|c|c|c|}
\hline \multirow{2}{*}{ Kategori } & Pre-Test & \multirow{2}{*}{$\begin{array}{c}\text { Presentase } \\
\text { Ketuntasan } \\
\text { Klasikal }\end{array}$} & Post-Test & \multirow{2}{*}{$\begin{array}{c}\text { Presentase } \\
\text { Ketuntasan } \\
\text { Klasikal }\end{array}$} \\
\hline & Jumlah Siswa & & Jumlah Siswa & \\
\hline Tuntas & 6 & $37 \%$ & 23 & $85 \%$ \\
\hline Tidak Tuntas & 21 & $63 \%$ & 4 & $17 \%$ \\
\hline Jumlah & 27 & $100 \%$ & 26 & $100 \%$ \\
\hline Rata-rata Kelas & 64,3 & & 82,8 & \\
\hline
\end{tabular}

Respon siswa terhadap pembelajaran dan perangkat pembelajaran yang digunakan di dalam pembelajaran meliputi respon positif dan respon negatif. Respon positif ditandai dengan pernyataanpernyataan positif seperti senang, baru, berminat terhadap komponen perangkat pembelajaran yang dikembangkan berbasis masalah. Sedangkan pernyataan negatif ditandai dengan pernyataanpernyataan seperti tidak senang, tidak baru dan tidak berminat dalam menggunakan komponen perangkat pembelajaran.

Berdasarkan kriteria perangkat pembelajaran yang praktis yaitu tim ahli menyatakan bahwa perangkat pembelajaran dapat digunakan dengan revisi kecil dan tercapainya target respon siswa, maka perangkat pembelajaran yang digunakan pada uji coba telah praktis.

Berdasarkan kriteria perangkat yang efektif yaitu tercapainya target ketuntasan belajar siswa, kemampuan guru mengelola pembelajaran serta waktu pembelajaran yang tidak berbeda jauh dengan waktu pembelajaran biasa maka perangkat pembelajaran yang digunakan pada uji coba telah efektif.

\section{Tahap Penyebaran (Diseminate)}

Setelah kriteria valid dan efektif dipenuhi pada uji coba, maka diperoleh perangkat final. Langkah selanjutnya adalah dilakukannya penyebaran terbatas berupa penyebaran perangkat final kepada forum MGMP di SMP An Nizam Medan yang ditandai dengan penyerahan perangkat pembelajaran kepada forum MGMP dengan harapan guru matematika yang tergabung dalam forum tersebut dapat menerapkan perangkat pembalajaran tersebut pada pembelajaran selanjutnya. Langkah utama setelah penyerahan perangkat final tersebut adalah dengan menyerahkan hasil pengembangan tersebut kepada seluruh populasi dalam penelitian ini. 
Pengembangan Perangkat Pembelajaran Berbasis ICT Memanfaatkan Power Point, Filmora, Whtasapp Grup, Google Classroom, dan Google Formulir Untuk Meningkatkan Keefektifan Pembelajaran, Hafizd Darmawan, Mangaratua M. Simanjorang, Hamidah Nasution

\section{KESIMPULAN}

Berdasarkan hasil analisis dan pembahasan dalam penelitian ini, dikemukakan beberapa simpulan sebagai berikut:

1. Perangkat desain pembelajaran berbasis ICT memanfaatkan power point, filmora, whatsapp grup, google classroom, dan googel formulir untuk meningkatkan keefektifan hasil belajar siswa yang dikembangkan sudah memenuhi kriteria valid, praktis dan efektif yakni :

a. Kevalidan dengan rata-rata validitas RPP sebesar 4,26, rata-rata validitas lembar kerja peserta didik sebesar 4,21, rata-rata validitas video pembelajaran sebesar 4,17 , rata-rata validitas tes hasil belajar sebesar 4,28, dengan kategori valid.

b. Kepraktisan ditinjau dari 1) Respon tim ahli atau validator yang menyatakan bahwa perangkat pembelajaran dapat digunakan dengan revisi kecil 2) Keterlaksanaan perangkat pembelajaran pada kriteria $I O=4,5$ tinggi.

c. Keefektifan ditinjau dari 1) Ketuntasan klasikal mencapai $85 \%$ yakni telah memenuhi kriteria ketuntasan yakni $\geq 85 \%$ siswa mencapai KKM. 2) Kemampuan guru dalam mengelola pembelajaran diperoleh rata-rata 4,1 atau dalam kategori "baik". 3) Pencapaian persentase waktu ideal aktivitas siswa berada dalam pencapaian waktu ideal aktivitas siswa. dengan toleransi waktu 5\%. .4) Respon siswa terhadap pembelajaran diperoleh rata-rata 95,02\%.

d. Peningkatan hasil belajar siswa menggunakan perangkat pembelajaran yang telah dikembangkan dilihat dari nilai $N$-gain pada uji coba I sebesar 0,4 meningkat menjadi 0,6 pada uji coba II, artinya berada dalam kategori "sedang".

2. Tanggapan guru terhadap desain pembelajaran berbasis ICT memanfaatkan power point, filmora, whatsapp grup, google classroom, dan google formulir dalam pembelajaran matematika yang telah dikembangkan ialah bagus digunakan pada pembelajaran dalam jaringan, tetapi terlalu banyak aplikasi sehingga membuat guru sedikit repot atau bekerja ekstra.

3. Tanggapan siswa terhadap desain pembelajaran berbasis ICT memanfaatkan power point, filmora, whatsapp grup, google classroom, dan google formulir dalam pembelajaran matematika yang telah dikembangkan ialah menarik dan bagus, tetapi tidak semua handphone atau smartphone dapat mengakses semua aplikasi-aplikasi yang disediakan.

\section{UCAPAN TERIMA KASIH}

Terima kasih saya ucapkan kepada dosen pembimbing Bapak Mangaratua M. Simanjorang, Ph.D. dan ibu Dr. Hamidah Nasution, M.Si. Terima kasih juga saya ucapkan untuk semua pihak yang membantu dalam menyelesaikan penelitian ini.

\section{REFERENSI}

Azriati, S. A. (2020). Pengembangan Media Pembelajaran Matematika Berbasis Macromedia Flash untuk Meningkatkan Kemampuan Spasial Siswa. Univeritas Negeri Medan. 
Daryanto. (2012). Model Pembelajaran Inovatif. Gava Media.

Hake, R. (1999). Analyzing Change/Gain Scores. Dept. of Physcis, Indiana University.

Kemendikbud. (2020). Pusat Pendidikan dan Pelatihan Pegawai Kementrian Pendidikan dan

Kebudayaan. https://pusdiklat.kemdikbud.go.id/surat-edaran-mendikbud-no-4tahun-2020tentang-pelaksanaan-kebijakan-pendidikan-dalam-masa-daruratpenyebaran-corona-virusdisease-covid-1-9/

Munadi. (2008). Media Pembelajaran Sebuah Pendekatan Baru. Gaung Persada Pers.

Peraturan Mentri Pendidikan Nasional Nomor 22 Tahun 2006 tentang Mata Pelajaran Matematika

Sinaga, B. (2007). Pengembangan Model pembelajaran matematika Berdasarkan Masalah Berbasis Budaya Batak (PBMB3). Universitas Negeri Surabaya.

Sudjana, N., \& Rivai, A. (1990). Media Pengajaran. Citra Aditya Bakti.

Susilo, A., Rumende, C. M., Pitoyo, C. W., Santoso, W. D., Yulianti, M., Sinto, R., \& Cipto, R. (2020). Coronavirus Disease 2019: Tinjauan Literatur Terkini Coronavirus Disease 2019: Review of Current Literatures. Jurnal Penyakit Dalam Indonesia, 7(1), 45-67.

Suswandari, M., Veteran, U., \& Nusantara, B. (2020). Pengaruh Daring Learning terhadap Hasil Belajar IPA Siswa Sekolah Dasar. In Sukohajo (Ed.), Prosiding. Sukohajo. Universitas Veteran Bangun Nusantara Sukoharjo.

Trianto. (2011). Model Pembelajaran terpadu Konsep, Strategi dan Implementasinya dalam Kurikulum Tingkat Satuan Pendidikan (KTSP). Bumi Aksara.

Undang Undang No. 20 Tahun 2003 tentang Sistem Pendidikan Nasional, Pasal 1

Yuliana. (2020). Corona virus diseases (COVID-19). Wellness and Healthy Magazibe, 2(1), 187-192. 